\title{
Distribution and Characterization of Armillaria Complex in Atlantic Forest Ecosystems of Spain
}

\author{
Nebai Mesanza ${ }^{1, *}$, Cheryl L. Patten ${ }^{2}$ and Eugenia Iturritxa ${ }^{1, *}$ \\ 1 Production and Plant Protection, Neiker Tecnalia, Apartado 46, Vitoria Gasteiz 01080, Spain \\ 2 Department of Biology, University of New Brunswick, P.O. Box 4400, Fredericton, NB E3B 5A3, Canada; \\ pattenc@unb.ca \\ * Correspondence: nebaimesanzaiturritza@gmail.com (N.M.); eiturritxa@neiker.eus (E.I.); \\ Tel.: +34-637-436-343 (E.I.)
}

Received: 9 May 2017; Accepted: 28 June 2017; Published: 30 June 2017

\begin{abstract}
Armillaria root disease is a significant forest health concern in the Atlantic forest ecosystems in Spain. The damage occurs in conifers and hardwoods, causing especially high mortality in young trees in both native forests and plantations. In the present study, the distribution of Armillaria root disease in the forests and plantations of the Basque Country is reported. Armillaria spp. were more frequently isolated from stands with slopes of $20-30 \%$ and west orientation, acid soils with high permeability, deciduous hosts, and a rainfall average above $1800 \mathrm{~mm}$. In a large-scale survey, $35 \%$ of the stands presented Armillaria structures and showed disease symptoms. Of the isolated Armillaria samples, $60 \%$ were identified using molecular methods as A. ostoyae, $24 \%$ as A. mellea, $14 \%$ as $A$. gallica, $1 \%$ as $A$. tabescens, and $1 \%$ as $A$. cepistipes. In a small scale sampling, population diversity was defined by somatic compatibility tests and Universally Primed-PCR technique. Finally, the pathogenicity of A. mellea, the species with the broadest host range, was determined on different tree species present in the Atlantic area of Spain in order to determine their resistance levels to Armillaria disease. A significant difference in disease severity was observed among tree species $(p<0.001)$, with Pinus radiata being the most susceptible tree species and Cryptomeria japonica the most resistant to $A$. mellea.
\end{abstract}

Keywords: Armillaria spp.; distribution; diversity; environmental factors; host susceptibility; UP-PCR

\section{Introduction}

About 40 species of Armillaria are known worldwide [1]. Seven are present in Europe: A. mellea (Vahl) P.Kumm., A. gallica Marxm. \& Romagn., A. ostoyae (Romagn.) Herink, A. tabescens (Scop.) Emel, A. cepistipes Velen., A. borealis Marxm. \& Korhonen, and A. ectypa (Fr.) Lamoure [2,3]. Many of these are pathogens that cause root and butt rot disease on a broad range of trees, shrubs and some herbaceous plants [4]. This disease is characterized by some general symptoms such as chlorotic leaves, progressive thinning of the crown, slower leader growth, and excess cone production. Evidence of infection may also include subcortical white mycelial fans, clusters of golden-brownish mushrooms near the tree base, rhizomorphs, rotten stringy-yellow wood with black lines (pseudosclerotia), rapid tree death without the loss of foliage, and/or basal resin or gum exudates $[5,6]$.

In general, conifers seem to be more susceptible to infection than hardwoods [7], although susceptibility depends on the specific Armillaria species involved $[2,8]$. The extent of damage caused by Armillaria is variable and is determined by factors such as the fungal species, the vigor of the host, interaction with other diseases, soil properties, climate, plantation management, and previous land uses, among others [9-14]. Therefore, forest susceptibility cannot be generalized [15]. The composition of the stand can also influence the range of infection; lower density of susceptible tree species and higher species diversity in different forest strata reduce the possibility of disease transmission [16,17]. 
Management procedures such as selective logging, early thinning, and the continued planting of susceptible or moderately susceptible species that are not very well adapted to the location increase the inoculum sources and the potential for spread of infection [14,18-20]. Thus, in comparison with natural forests the damage in exotic tree plantations is usually greater [8].

In field conditions, Armillaria can colonize different hosts by direct contact between an infected source and roots by way of hyphae, or by advancing through the ground from an infection point by way of rhizomorphs [21]. This is a short distance spreading mechanism but it is considered the most important even if, for some Armillaria species, formation of rhizomorphs in the field is not common $[3,15]$. The capacity to create new infection points by releasing basidiospores varies from one species to another [22] but, in general, this seems to be the least frequent source of infection [23].

The genotypic diversity within a population is an important parameter for the determination of the epidemiology of a disease. Many different small somatic compatibility (SC) groups in a stand imply that spread is predominantly by basidiospores, and a single extensive SC group implies spread by vegetative mycelium. By means of SC tests, Armillaria population structure in the field can be determined [24]. Even though SC tests are usually reliable, sometimes they do not differentiate among closely related individuals of Armillaria [2]. Molecular techniques such as Universally primed-PCR (UP-PCR) [25] could provide more information in these cases. UP-PCR has been used for the characterization of fungal populations at interspecies and/or intraspecies level [26-28]. In this technique, the entire genome of an organism is targeted with a single primer or a combination of primers that will anneal to multiple regions resulting in a multiband profile which differs among different genotypes. Universal primers consist of a stable minisatellite-like region, with high GC content, designed using as a template genome regions of different organisms, which allows primer annealing at high temperatures resulting in reproducible PCR product patterns, and a variable, randomly designed region. Highly variable intergenic regions are usually targeted which enables differentiation between closely related isolates [29].

Armillaria spp., including the primary parasites A. ostoyae and A. mellea, have been previously reported in Northern Spain [30-32] including the Basque Country [33]. The main tree species in Basque Country plantations is Pinus radiata D. Don. (covering an area of 132,084 ha), followed by Eucalyptus spp. (15,197 ha), P. nigra Arn. (13,701 ha), Larix sp. (8011 ha), P. pinaster Ait. (7238 ha), Pseudotsuga menziessi Franco (6537 ha), Chamaecyparis lawsoniana Parl. (3414 ha), Quercus rubra L. (3328 ha) and Picea abies (L.) H. Karst. (525 ha). The main native forest species are Fagus sylvatica L. (53,835 ha), Q. faginea Lam. (26,652 ha), Q. ilex L. (26,152 ha), Q. robur L. and Q. petraea (Matt.) Liebl. association (16469 ha), and Q. pyrenaica Willd. (13,039 ha) [34]. All of these tree species have been reported to be susceptible to different Armillaria spp. in the literature, however, Armillaria spp. distribution, species diversity, and dispersal mechanisms are not known in the Basque Country, where the wood industry is valued at 1 billion euros per year [35]. Thus, the objectives of this study were to determine: (i) the Armillaria species distribution and population diversity in this region; (ii) factors affecting Armillaria spp. Distribution; and (iii) host susceptibility. This will contribute to a better understanding of the impact of Armillaria spp. and establishment of management practices.

\section{Materials and Methods}

\subsection{Collection of Fungi}

Fungal samples and data related to forest characteristics were collected from native forests and plantations of the Basque Country, northern Spain, focusing on trees in pockets of mortality and decayed trees that displayed symptoms resembling those of root rot diseases. For the first sample set (Set 1), the stands were surveyed by systematic random sampling in which samples were collected systematically from randomly chosen focal points [36]. A total of 709 foci of tree mortality were examined for the presence of Armillaria spp., and fungal samples and ecosystem characteristics related to infection were collected. The second sampling (Set 2) was carried out to determine the genetic 
diversity and population structure patterns of the fungus within a plot, and consisted of a detailed survey of three specific areas of approximately $500 \times 500 \mathrm{~m}$ with high presence of Armillaria spp., located in Otxandiano (Vizcaya), Amunategi (Vizcaya) and Altube (Álava) (Figure 1). In both sample sets, all the surveyed points, including sites of fungus collection, were georeferenced using an Oregon 300 Garmin GPS.

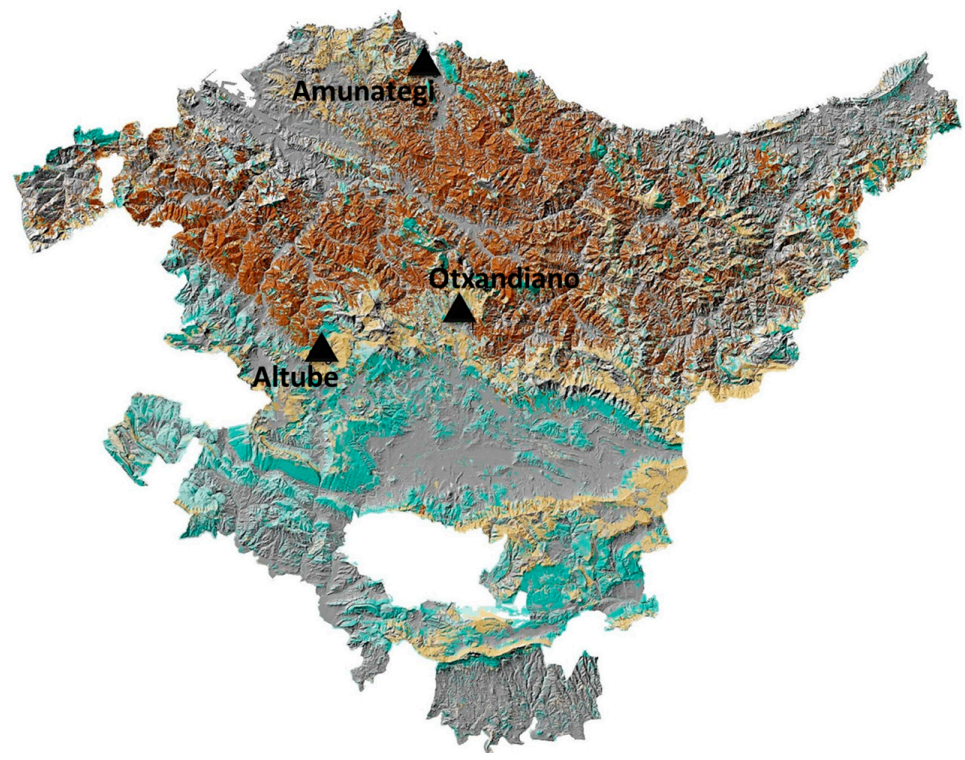

Figure 1. Location of Amunategi, Altube, and Otxandiano stands.

Samples of Armillaria spp. basidiocarps, rhizomorphs and mycelia were collected and placed in separate polyethene bags, transported to the laboratory, and stored at $4{ }^{\circ} \mathrm{C}$. Fungi were cultured on benomyl-dichloran-streptomycin agar (BDS) [37] and grown at $20^{\circ} \mathrm{C}$ in the dark. Pure cultures were obtained, and routinely grown on malt extract agar (MEA) (PanReac Química, Barcelona, Spain). For preservation of the pure cultures, mycelial fragments were placed in $50 \%$ glycerol and, after incubating at $4{ }^{\circ} \mathrm{C}$ for $24 \mathrm{~h}$, maintained at $-20^{\circ} \mathrm{C}$ [38].

\subsection{Description of Armillaria-Infected Ecosystems}

To determine environmental factors of Armillaria spp. habitats, a dataset of the environmental variables of the studied ecosystems was constructed based on information supplied by the Environment Department of the Basque Government (http://www.ingurumena.ejgv.euskadi.eus/r49-579/es/ /publicaciones_c.htm). The variables compiled were stand slope, stand orientation, soil pH, soil permeability, average rainfall, average temperature, tree types, and host optimal conditions. Variables were categorized as shown below. Armillaria spp. presence was coded as a binomial variable being 0 for absence and 1 for presence.

As a preliminary exploratory analysis, multiple correspondence analysis (MCA) was applied to represent the relationships among the categorical variables, including Armillaria spp. presence. MCA projects the variables in a reduced space, facilitating visual interpretation of large datasets. This analysis converts a matrix of data into a graphical display known as factor planes. The rows and columns of the matrix are plotted as points in the factor planes and allow a geometrical representation of the information [39].

This procedure was complemented with contingency tables testing separately each categorical variable including its categories against Armillaria presence or absence. Pearson's chi square test was used to determine the independence between row and column variables, i.e., to determine if Armillaria spp. were more frequently detected than expected by chance in certain categories. For calculating the strength of association between categorical variables Cramer's V was used; Cramer's V ranges between 
0 (no relationship) and 1 (perfect relationship). Adjusted standardized residuals were checked in order to determine the significant differences between categories; adjusted residuals are standardized values allowing comparisons among different cells, and follow a standard normal frequency (with mean zero and standard deviation one) so it can be assumed that if their value lies outside of \pm 1.96 then it is significant at $p<0.05$, if it lies outside \pm 2.58 then it is significant at $p<0.01$ and if it lies outside \pm 3.29 then it is significant at $p<0.001$ [40]. All of the analyses were carried out in SPSS version 15.0 (SPSS Inc., Chicago, IL, USA).

\subsection{Fungus Identification and Diversity Analysis}

\subsubsection{Fungal Species Identification by RFLP-PCR}

Restriction Fragment Length Polymorphism (RFLP)-PCR was used to confirm the species identity of the Armillaria isolates in sample sets 1 and 2 at the species level. DNA from two-week-old pure cultures was extracted with DNeasy Plant Mini Kit (QIAGEN Gmb, Hilden, Germany) in accordance with the manufacturer's instructions. A region of the intergenic spacer (IGS) of the rDNA was amplified using the primer pair LR12R (5'-CTGAACGCCTCTAAGTCAGAA-3') and O-1 (5'-AGTCCTATGGCCGTGGAT-3') [41]. The PCR mixture contained $1.5 \mathrm{mM} \mathrm{MgCl} 2,200 \mu \mathrm{M}$ each dNTP, $0.5 \mu \mathrm{M}$ each primer, $2 \mathrm{U}$ Taq polymerase (Netzyme, Molecular Netline Bioproducts, Valencia, Spain) and $1 \mu \mathrm{L}$ template DNA in a final volume of $50 \mu \mathrm{L}$. The cycling conditions consisted of $90 \mathrm{~s}$ at $95^{\circ} \mathrm{C}, 35$ cycles of $30 \mathrm{~s}$ at $95^{\circ} \mathrm{C}, 40 \mathrm{~s}$ of annealing at $60^{\circ} \mathrm{C}$, and $2 \mathrm{~min}$ at $72^{\circ} \mathrm{C}$, and a final $10 \mathrm{~min}$ at $72^{\circ} \mathrm{C}$. The obtained DNA fragment was directly digested with the restriction enzyme Alu I (Invitrogen Life Technologies, Carlsbad, CA, USA), Nde I (Takara Bio Inc., Kusatsu, Japan) or Bsm I (Hoffmann-La Roche Ltd., Basel, Switzerland) [34]. The restriction fragments were separated in $3 \%$ agarose gels (agarose D-1 Low EEO, Conda, Madrid, Spain). Species were identified based on the restriction patterns determined by Harrington and Wingfield [41] and Sierra et al. [42].

\subsubsection{Fungal Population Analysis}

In order to determine mechanisms of dispersal of Armillaria spp. at the stand level, genetic diversity and population structure patterns of the Armillaria isolates from Set 2 were analyzed. Armillaria species were determined by RFLP-PCR (as described above) and intraspecies differentiation was determined by SC tests and UP-PCR. For determination of SC groups (SCGs), diploid isolates from the same sampling area were paired in all possible combinations. Approximately $4 \mathrm{~mm}^{2}$ of mycelia were placed $0.5 \mathrm{~cm}$ apart on MEA plates, and incubated at $20{ }^{\circ} \mathrm{C}$ for six weeks. When mycelia of co-cultured isolates fused and grew with a uniform morphology, they were considered to belong to the same species and genet, and the pairings were considered somatic compatible. When a line of demarcation was apparent, isolates were considered somatic incompatible [43].

UP-PCR reactions were carried out following the procedure described by Tyson et al. [44], in $25 \mu \mathrm{L}$ volumes containing $2 \mathrm{mM} \mathrm{MgCl} 2,0.2 \mathrm{mM}$ each dNTP, $0.8 \mu \mathrm{M}$ primer (Table 1 ), 50 ng genomic DNA (extracted as for RFLP analysis), and 1.25 U Taq DNA Polymerase (Invitrogen Life Technologies, Carlsbad, CA, USA). The cycling conditions were $5 \mathrm{~min}$ at $94{ }^{\circ} \mathrm{C}, 5$ cycles of $50 \mathrm{~s}$ at $94{ }^{\circ} \mathrm{C}, 2 \mathrm{~min}$ at primer specific annealing temperature (Table 1), and then $1 \mathrm{~min}$ at $72{ }^{\circ} \mathrm{C}$, followed by 30 cycles of 50 $\mathrm{s}$ at $94{ }^{\circ} \mathrm{C}, 90 \mathrm{~s}$ at primer specific annealing temperature, and $1 \mathrm{~min}$ at $72{ }^{\circ} \mathrm{C}$, and a final extension at $72{ }^{\circ} \mathrm{C}$ for $7 \mathrm{~min}$ [44]. UP-PCR primers were tested on a representative group of Armillaria isolates consisting of different species and genets of Armillaria (as determined by RFLP-PCR and mating tests), and the primers with the best capacity to distinguish between different SCGs and species were chosen for the analysis of all the isolates. Following gel electrophoresis of the UP-PCR amplicons, the band pattern for each isolate was assessed for the presence (1) or absence (0) of each band and represented in a binomial matrix. Similarities between strains were calculated using a simple matching coefficient [45] and represented on dendrograms constructed by average linkage between groups in 
SPSS software (SPSS Inc., Chicago, IL, USA). To determine the consistency between the similarity matrix and dendrograms, the cophenetic correlation coefficient was calculated [46].

Table 1. Oligonucleotide sequence of the UP-PCR primers and their respective annealing temperatures [44].

\begin{tabular}{|c|c|c|c|}
\hline Primer & Primer Sequence & ng Temp. $\left({ }^{\circ} \mathrm{C}\right)$ & References \\
\hline $0.3-1$ & 5'-CGAGAACGACGGTTCT-3' & 50 & [47] \\
\hline 3.2 & 5'-TAAGGGCGGTGCCAGT-3' & 52 & [47] \\
\hline L45 & $5^{\prime}$-GTAAAACGACGGCCAGT-3' & 51 & [29] \\
\hline AS15inv & $5^{\prime}$-CATTGCTGGCGAATCGG-3' & 52 & {$[48]$} \\
\hline AA2M2 & 5'-CTGCGACCCAGAGCGG-3' & 50 & [49] \\
\hline AS4 & 5'-TGTGGGCGCTCGACAC-3' & 55 & [49] \\
\hline Fok1 & $5^{\prime}$-GGATGACCCACCTCCTAC-3' & 52 & [49] \\
\hline L15/AS19 & $5^{\prime}$-GAGGGTGGCGGCTAG-3' & 52 & {$[50]$} \\
\hline L21 & $5^{\prime}$-GGATCCGAGGGTGGCGGTTCT-3 & 58 & {$[51]$} \\
\hline M13 & 5'-GAGGGTGGCGGTTCT-3' & 52 & [52] \\
\hline AS15 & $5^{\prime}$-GGCTAAGCGGTCGTTAC-3' & 52 & {$[47]$} \\
\hline
\end{tabular}

\subsection{Host Resistance}

To assess the susceptibility to A. mellea of different tree species present in the Basque Country, 2-year-old trees of different species, including P. radiata, P. nigra subsp. salzmannii var. corsicana, P. sylvestris L., Fagus sylvatica, Prunus avium, Q. petraea, Q. ilex, Cryptomeria japonica (Thunb. ex L.f.) D.Don, Q. robur, Sequoiadendron giganteum (Lindl.) J.Buchholz, and Eucalyptus nitens H.Deane \& Maiden (Explotaciones Forestales Jiménez Araba s. 1. Nursery, Vitoria, Spain), were infected with the A. mellea strain AMVac isolated from an Acer pseudoplatanus L. (the fungal strain is maintained in a collection at Neiker Tecnalia, Arkaute, Spain). For the preparation of A. mellea inoculum, pieces of fungal mycelia were placed on BDS agar with autoclaved Quercus spp. acorns and incubated for approximately one month at room temperature in the dark [53]. Fifty trees of each species were grown in $53 \times 53 \times 180 \mathrm{~mm}$ pots ( $300 \mathrm{cc}$ volume) using a mix of peat moss $(2 / 3$ peat, $1 / 3$ perlite and fertilizer NPK; $\mathrm{N}=200-450 \mathrm{mg} / \mathrm{L}, \mathrm{P}_{2} \mathrm{O}_{5}=200-500 \mathrm{mg} / \mathrm{L}, \mathrm{K}_{2} \mathrm{O}=300-550 \mathrm{mg} / \mathrm{L}$ ) and, after an adaptation period of two weeks, half acorns infected with $A$. mellea mycelium was placed in contact with tree roots. The seedlings were maintained for 4 months in a biosafety level 2 greenhouse at a mean temperature of $18 \pm 5^{\circ} \mathrm{C}$, with a relative humidity of $55-60 \%$ and without supplemental light. After this period, roots were cleaned with tap water and lengths of stems, main roots and secondary roots were measured. A. mellea mycelial colonization was determined after removing the bark from the stem and roots. Plants were scored as healthy (without symptoms of infection) or with lesions (when A. mellea mycelium was present under the bark); the length of the lesions was determined by removing the bark of stem and roots and measuring the extent of Armillaria damage with an electronic caliper.

The differences in Armillaria disease severity among different tree species was determined by Pearson's chi-square. The strength of association between categorical variables (tree species and healthy or lesion containing trees) was measured with Cramer's V; adjusted standardized residuals were checked in order to determine the significant differences between categories. Differences in the size of the fungal lesions among tree species was analyzed by Brown-Forsythe and Welch statistics, and Games-Howell test was chosen for the post hoc analysis. The data was not normally distributed and therefore a base10- log transformation was applied. 


\section{Results}

\subsection{Distribution of Armillaria spp.}

The presence of Armillaria spp. was detected in 248 (34.97\%) of the 709 foci surveyed (Figure 2). Basidiocarps were mainly found in the root collars of dead and living trees, and stumps; some were found growing from superficial roots. Rhizomorphs were found in the aforementioned tree structures and also in the soil. The tree species on which Armillaria spp. was present were P. radiata, P. nigra, P. pinaster, Q. robur, Q. pirenaica, Fraxinus excelsior L., Alnus glutinosa (L.) Gaertn., F. sylvatica, E. globulus Labill., P. abies, Larix kaempferi (Lamb.) Carr., P. sylvestris, Populus alba L., Pseudotsuga menziesii (Mirb.) Franco, Q. faginea, Q. ilex, Robinia pseudoacacia L., and C. lawsoniana.

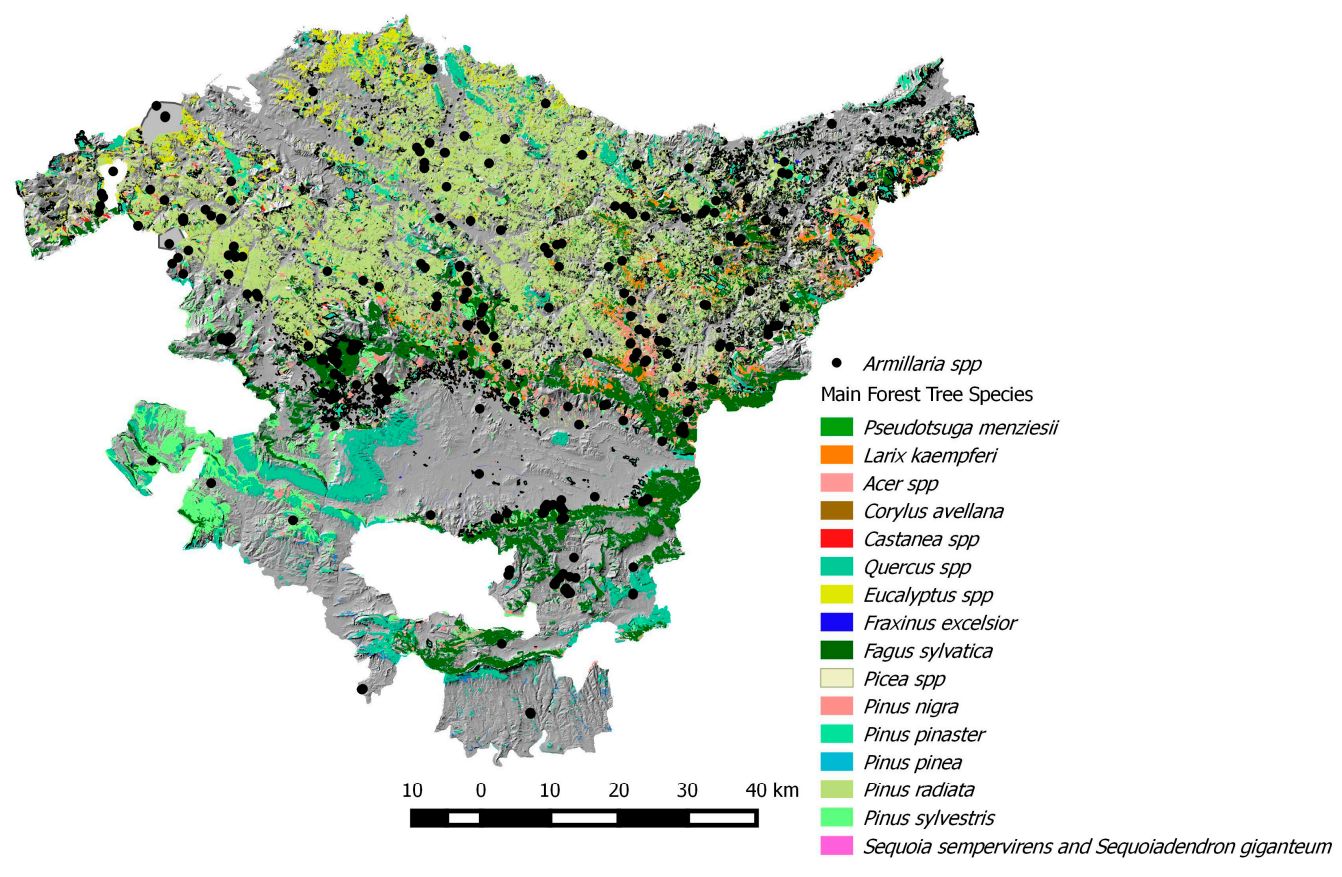

Figure 2. Distribution of Armillaria spp. and main forest tree species of the Basque Country.

Of the total of isolates obtained from the surveyed plots (Set 1), 60\% were identified by RFLPPCR patterns as A. ostoyae, $24 \%$ as A. mellea, $14 \%$ as A. gallica, $1 \%$ as A. tabescens and $1 \%$ as A. cepistipes. A. ostoyae was detected mainly in Pinus spp. (P. radiata, P. nigra and $P$. pinaster). The host range for A. mellea was more varied. A. mellea pattern 1 (PCR fragment sizes: 320 and $155 \mathrm{bp}$ ) was found on P. radiata, Quercus spp., F. excelsior, and C. lawsoniana, and corresponded to $53 \%$ of the $A$. mellea isolates, while the remaining 47\% were identified as pattern 2 (fragment sizes: 320, 180, and $155 \mathrm{bp}$ ) and appeared on Q. pyrenaica and P. radiata. A. gallica was found on A. glutinosa, P. radiata, and Q. robur, $A$. cepistipes was detected on $P$. radiata, and $A$. tabescens on $Q$. robur.

\subsection{Determination of Ecosystem Characteristics in Which Armillaria spp. Were Detected}

Environmental characteristics were associated with each of the surveyed points and their relationships with the presence of Armillaria spp. was assessed (Table 2). The spread of the category variables for all characteristics is represented in a MCA that reflects the relationships among the variables in each dimension. MCA revealed that the first horizontal dimension explained $23.7 \%$ of the total inertia (variance), as the first factor plane represents the largest inertia, while the second vertical dimension explained $22.7 \%$. A measure of the importance of each variable (squared component loading) is computed for each dimension. This measure is also the variance of the quantified variable in that dimension. The variables with higher variance in the first dimension were average rainfall 
(Rain), optimal conditions for host growth (Hoc), slope, Armillaria spp., soil permeability, and stand orientation (Figure 3). The variables with higher variance in the second dimension were orientation, average temperature (Temperature), average rainfall (Rain), slope, and soil acidity (Soil) (Figure 3). Armillaria spp. detection was related to categories such as west, northwest, and northeast stand orientation, slopes between $20 \%$ and $50 \%$, basic soils, high average rainfalls (>1800 mm), and high soil permeability (Figure 4). Armillaria spp. absence was related to categories such as south and southeast stand orientation, slopes less than $20 \%$ and soils with medium permeability (Figure 4).

Table 2. Characteristics of the plots included in this study.

\begin{tabular}{|c|c|c|c|c|c|}
\hline \multirow{2}{*}{ Characteristics } & \multirow{2}{*}{$\begin{array}{l}\text { Category } \\
\text { Code }\end{array}$} & \multirow[t]{2}{*}{${ }^{*}$ Description } & \multicolumn{2}{|c|}{$\begin{array}{c}\text { Detection of } \\
\text { Armillaria Disease }\end{array}$} & \multirow{2}{*}{$\begin{array}{c}\text { Number } \\
\text { of foci }\end{array}$} \\
\hline & & & $\begin{array}{l}\text { Negative } \\
\text { (Arm-) }\end{array}$ & $\begin{array}{c}\text { Positive } \\
(\text { Arm+) }\end{array}$ & \\
\hline \multirow{6}{*}{ Slope (\%) } & $<10$ & $<10$ & 170 & 29 & 199 \\
\hline & $10-20$ & $10<20$ & 133 & 57 & 190 \\
\hline & $20-30$ & $20<30$ & 89 & 111 & 200 \\
\hline & $30-40$ & $20<40$ & 48 & 34 & 82 \\
\hline & $40-50$ & $40<50$ & 18 & 13 & 31 \\
\hline & $50-60$ & $50<60$ & 3 & 4 & 7 \\
\hline \multirow{2}{*}{ Tree Type } & Deciduous & Deciduous & 28 & 36 & 64 \\
\hline & Conifers & Conifers & 433 & 212 & 645 \\
\hline \multirow{8}{*}{ Orientation } & $\mathrm{N}$ & North & 45 & 24 & 69 \\
\hline & NE & Northeast & 46 & 26 & 72 \\
\hline & $\mathrm{E}$ & East & 53 & 32 & 85 \\
\hline & SE & Southeast & 39 & 26 & 65 \\
\hline & $\mathrm{S}$ & South & 75 & 28 & 103 \\
\hline & SW & Southwest & 133 & 26 & 159 \\
\hline & $\mathrm{W}$ & West & 45 & 73 & 118 \\
\hline & NW & Northwest & 25 & 13 & 38 \\
\hline \multirow{4}{*}{ Soil (Acidity) } & acid & acid & 260 & 184 & 444 \\
\hline & -acid & -acid & 118 & 31 & 149 \\
\hline & -basic & -basic & 46 & 17 & 63 \\
\hline & basic & basic & 37 & 16 & 53 \\
\hline \multirow{4}{*}{ Permeability } & Imper & Impermeable & 31 & 2 & 33 \\
\hline & low & Low & 4 & 5 & 9 \\
\hline & medium & Medium & 364 & 175 & 539 \\
\hline & high & High & 62 & 66 & 128 \\
\hline \multirow{4}{*}{$\begin{array}{c}\text { Rain (average, } \\
\mathrm{mm} \text { ) }\end{array}$} & 1 & $<1000$ & 34 & 7 & 41 \\
\hline & 2 & 1000-1400 & 86 & 44 & 130 \\
\hline & 3 & 1400-1800 & 295 & 141 & 436 \\
\hline & 4 & $>1800$ & 46 & 56 & 102 \\
\hline \multirow{4}{*}{$\begin{array}{l}\text { Temperature } \\
\text { (average, }{ }^{\circ} \mathrm{C} \text { ) }\end{array}$} & 1 & $<10.5$ & 20 & 5 & 25 \\
\hline & 2 & $10.5-11.5$ & 130 & 74 & 204 \\
\hline & 3 & $11.5-12.5$ & 162 & 94 & 256 \\
\hline & 4 & $>12.5$ & 149 & 75 & 224 \\
\hline \multirow{4}{*}{$\begin{array}{l}\text { HOC (Host } \\
\text { Optimal } \\
\text { Conditions) }\end{array}$} & $+\mathrm{Op}$ & Favorable & 241 & 125 & 366 \\
\hline & Op & Acceptable & 171 & 103 & 274 \\
\hline & $-O p$ & $\begin{array}{c}\text { Unfavorable } \\
\text { Very }\end{array}$ & 23 & 13 & 36 \\
\hline & $-\mathrm{Op}$ & Unfavorable & 26 & 7 & 33 \\
\hline
\end{tabular}




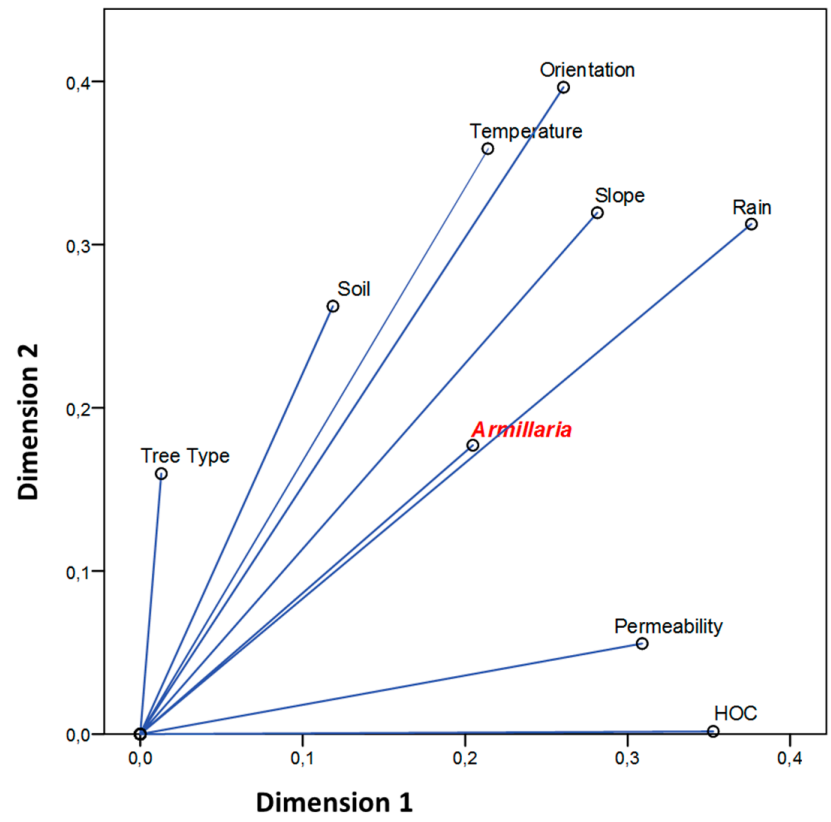

Figure 3. Measure of the variance of each variable for each dimension. The variables with higher variance in the first dimension were mainly average rainfall (Rain), optimal conditions for host growth (Hoc), slope, Armillaria spp., soil permeability and stand orientation (Figure 3). The variables with higher variance in the second dimension were orientation, average temperature (Temperature), average rainfall (Rain), slope, and soil acidity (Soil).

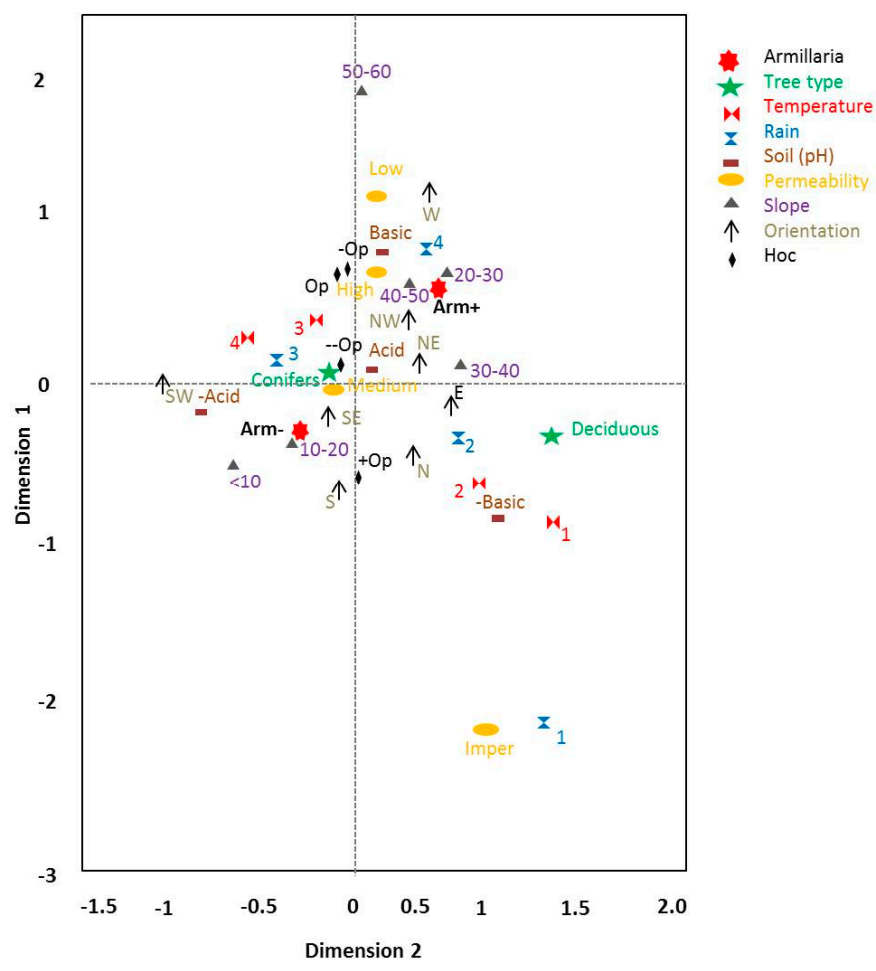

Figure 4. Location in an Euclidean space of the presence or absence of Armillaria spp. and environmental categories. The first two dimensions of the Euclidean space of the MCA are plotted to examine the associations among categories. The values on the axes indicate the coordinates within the Euclidean space in which categories are located. Variable description can be found in Table 2. 
The significance of the associations among fungal presence and the environmental variables was determined using Pearson's chi square test and the strength of the association was determined by Cramer's V. A significant association was observed between Armillaria spp. and slope, tree type, soil acidity, soil permeability, and rainfall average (Table 3). When the adjusted standardized residuals were examined, Armillaria spp. were significantly present in stands with slopes of $20-30 \%(z=7.2$; $p<0.001)$; stands with western orientation $(z=6.7 ; p<0.001)$; deciduous hosts $(z=3.7 ; p<0.001)$; acid soils $(z=4.7 ; p<0.001)$; high permeability soils $(z=4.3 ; p<0.001)$, and rainfall average $(\mathrm{mm})$ $>1800$ ( $z=4.6 ; p<0.001)$ (Figure 5). Armillaria spp. were significantly absent in stands with slopes $<10 \%(z=-7.1 ; p<0.001)$; stands with southwestern orientation $(z=-5.6 ; p<0.001)$; coniferous hosts $(z=-3.7 ; p<0.001)$; moderately acid soils $(z=-4.1 ; p<0.001)$; medium permeability soils $(z=-2.5$; $p<0.01)$, impermeable soils $(z=-3.6 ; p<0.01)$, and rainfall average $(\mathrm{mm})<1000(z=-2.5 ; p<0.05)$ (Figure 5).

Table 3. Environmental variables for which a significant association with Armillaria spp. was observed. Pearson's chi square value $\left(\chi^{2}\right)$, degrees of freedom (df), $p$-value, Cramer's V value, and effect size are shown for each environmental variable.

\begin{tabular}{cccccc}
\hline Environmental Variables & df & $\chi^{\mathbf{2}}$ & $p$-Value & Cramer's V & Effect Size \\
\hline Slope $(\%)$ & 5 & 79.2 & $<0.001$ & 0.334 & medium-large \\
Orientation & 7 & 65.5 & $<0.001$ & 0.304 & medium-large \\
Tree type & 1 & 14.0 & $<0.001$ & 0.140 & small-medium \\
Soil acidity & 3 & 23.6 & $<0.001$ & 0.183 & small-medium \\
Soil permeability & 3 & 30.8 & $<0.001$ & 0.208 & small-medium \\
Rainfall average $(\mathrm{mm})$ & 3 & 25.0 & $<0.001$ & 0.188 & small-medium \\
\hline
\end{tabular}

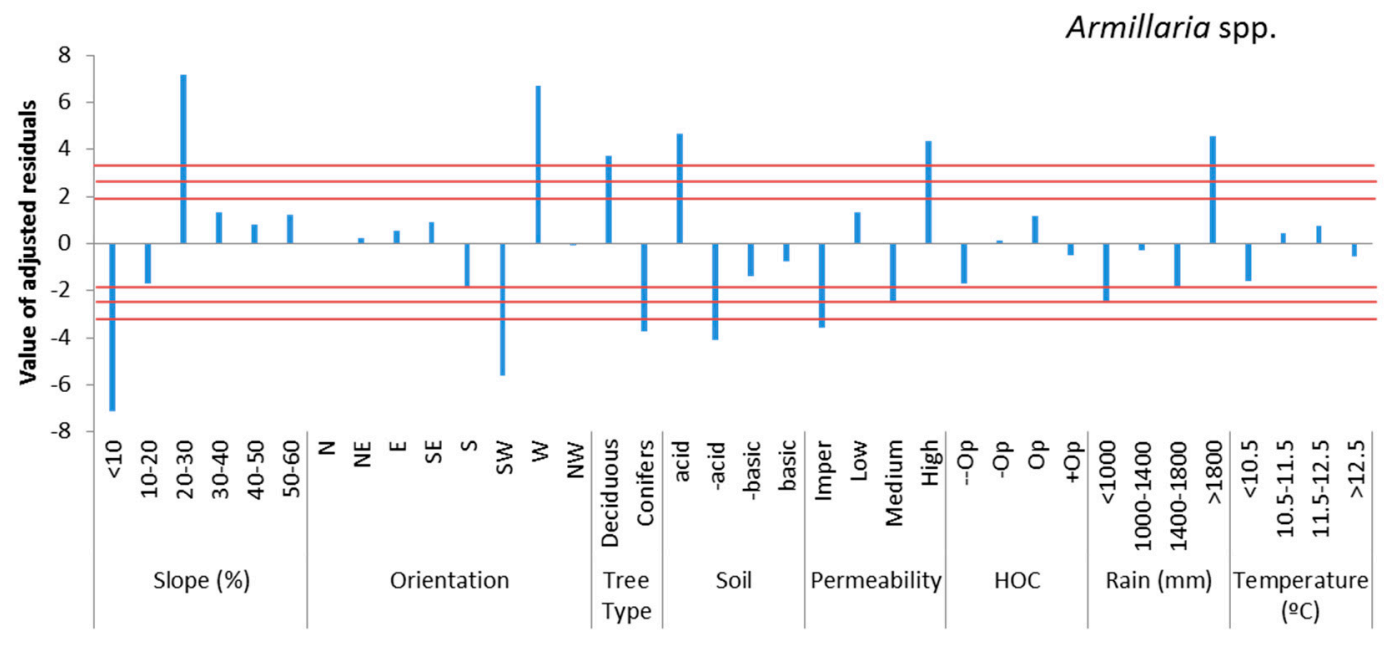

Figure 5. Values of the adjusted residuals (blue bars) for each category within a categorical variable for the presence of Armillaria spp. Red lines represent the value the adjust residuals must have to consider a category significant; if $\mathrm{y}= \pm 1.96$ then it is significant at $p<0.05$, if $\mathrm{y}= \pm 2.58$ then it is significant at $p<0.01$, and if $\mathrm{y}= \pm 3.29$ then it is significant at $p<0.001$ (Field, 2009).

\subsection{Fungal Population Analysis by RFLP, SI and UP-PCR}

Analysis of fungal samples (Set 2) for determining the mechanism of Armillaria spp. dispersal in three specific plots in Otxandiano, Amunategi, and Altube (Figure 1) revealed three different Armillaria species, A. mellea, A. ostoyae and A. gallica. The 21 samples collected in the stand located in Otxandiano belonged to the same SCG and were identified as $A$. ostoyae (data not shown). They were found in Q. robur stumps and trees, C. lawsoniana, Crataegus monogyna Jacq., and grassland. In the stand located in Amunategi, four of the 19 isolates were classified as A. mellea RFLP pattern 2 that belonged to two SCGs, both present in R. pseudoacacia, and 15 isolates as A. gallica in a more complex population 
structure located in R. pseudoacacia, Salix alba L. and stumps of deciduous trees (Figure 6). In the stand located in Altube, nine of the 17 samples were identified as A. ostoyae, separated in 3 SCGs, in F. sylvatica and Q. robur, seven as A. mellea pattern 2, separated in 3 SCGs, in F. sylvatica and C. monogyna, and one as A. mellea pattern 1 in F. sylvatica (Figure 6). The larger size of A. ostoyae SCGs indicates dispersal predominantly by vegetative mycelium. In contrast, the smaller SCGs obtained for A. mellea and A. gallica indicate dispersal by basidiospores and vegetative mycelium. The location in the stands from which the samples were collected, the groups obtained by SC tests and their extension are depicted in Figure 7.
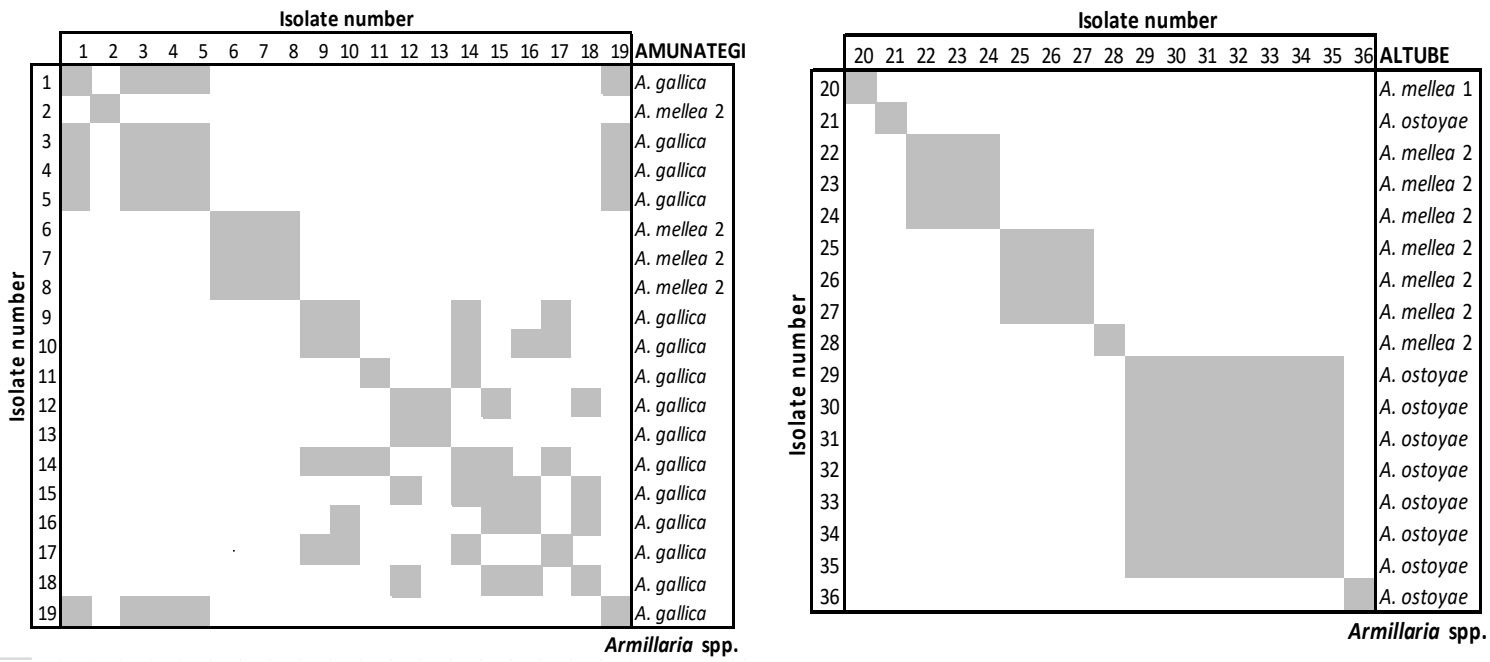

Figure 6. Fungal population analysis by mycelial pairings. Grey squares indicate strains belonging to the same SCG; white squares correspond to non-compatible strains. Paired sets shown on the left correspond to samples collected in Amunategi, paired sets shown on the right correspond to samples collected in Altube.

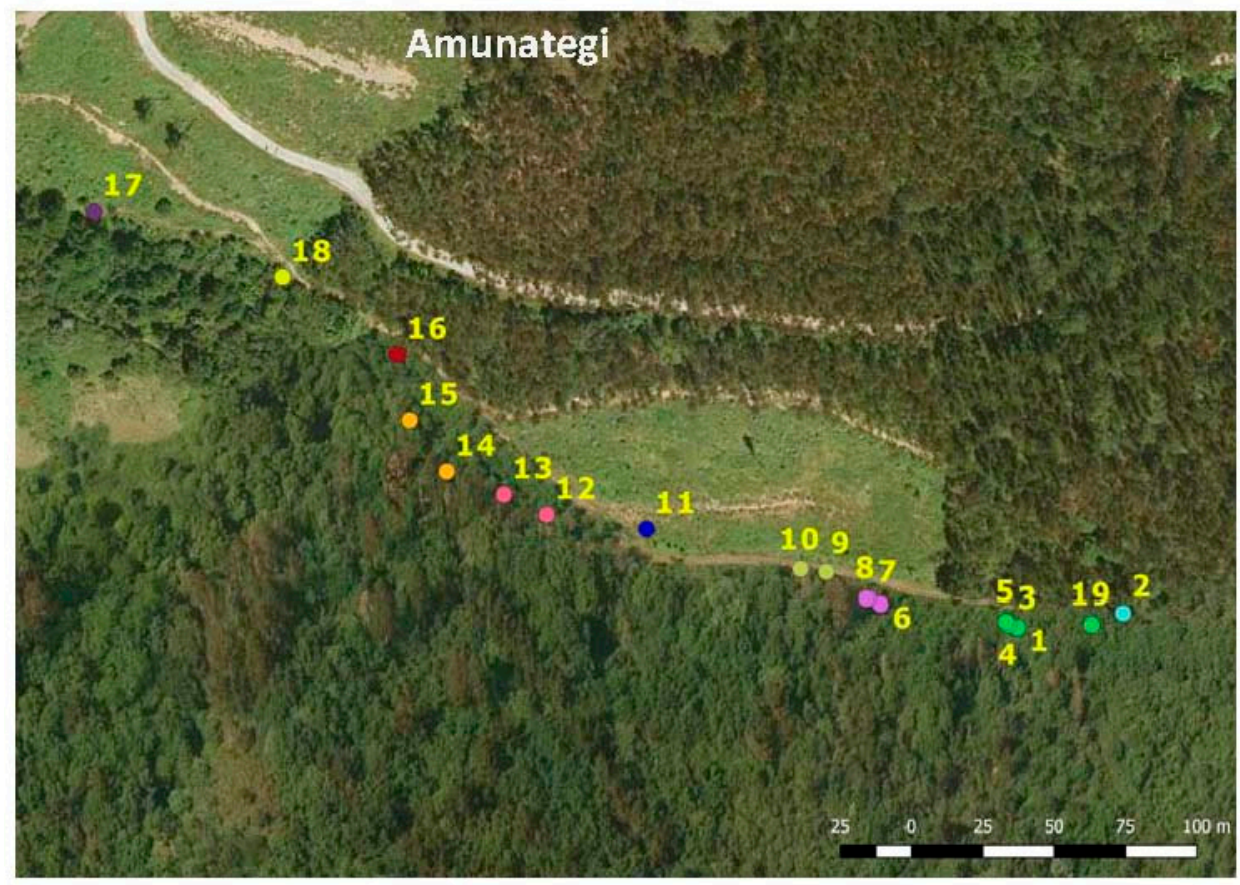

Figure 7. Cont. 

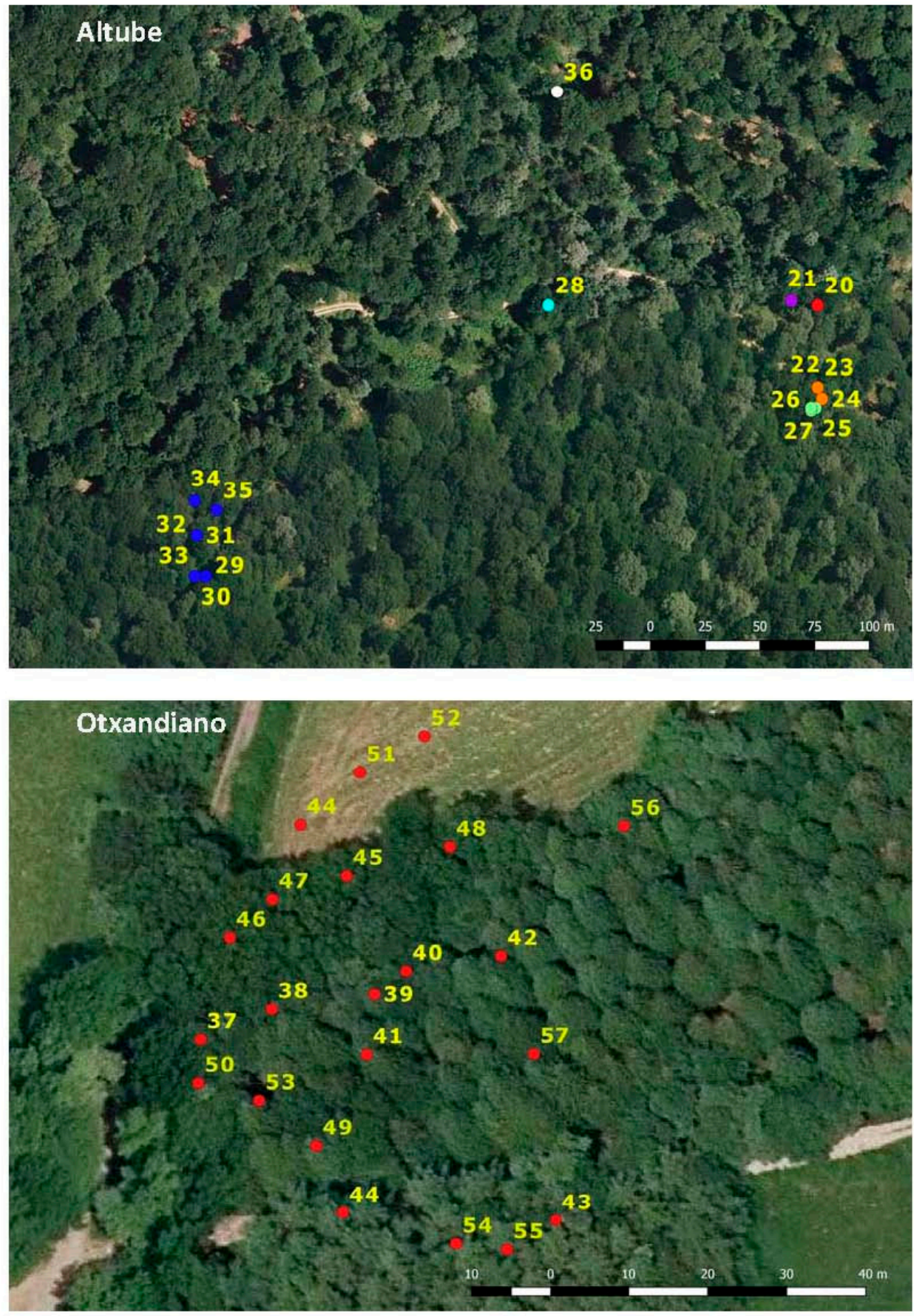

Figure 7. Spatial distribution of the infected trees and Armillaria spp. genotypes. Numbers correspond to Armillaria spp. isolates. Same genotype is marked with the same color. From top to bottom, stand located in Amunategi, stand located in Altube, and stand located in Otxandiano.

UP-PCR primer AS4 showed good ability to distinguish the fungal strains at the interspecies and intraspecies levels. Although primer L15/AS19 showed good discrimination in the initial screen, it did not yield specific banding profiles when all the samples where tested (data not shown). The best differentiation patterns were obtained for $A$. ostoyae strains and in general the clusters were comparable to those generated from mycelia matings (Figure 8). The cophenetic correlation coefficient between the similarity matrix and the dendrogram was 0.886 , meaning that the clustering had a good fit. 


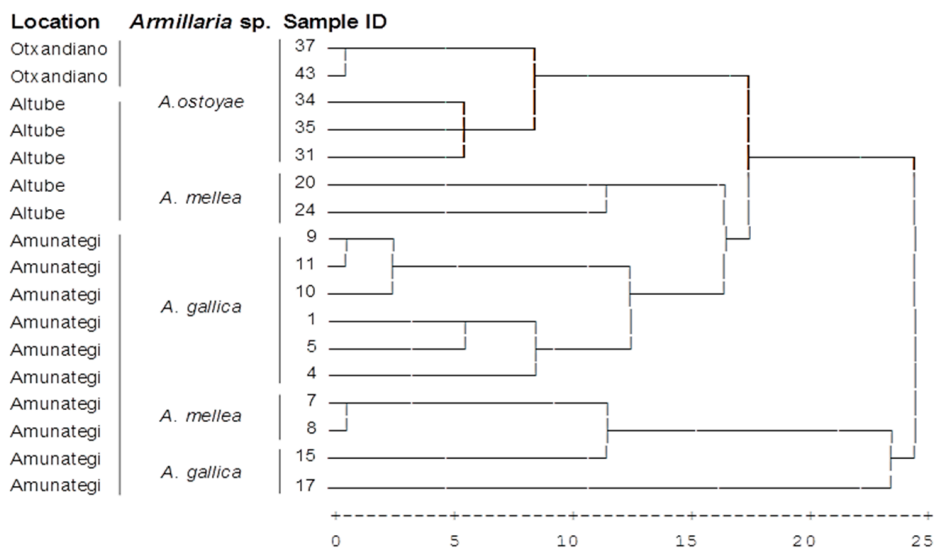

Figure 8. Genetic relationships among Armillaria strains. The dendrogram was generated by the average-linkage method of clustering using the distances calculated by simple matching coefficient among the binomial matrix obtained from UP-PCR banding patterms using AS4 universal primers.

\subsection{Host Resistance}

A significant difference in disease severity was observed among tree species $\left(\chi^{2}(10)=83.154\right.$, $p<0.001$ ), and a Cramer's V of 0.454 indicated a medium-large effect size between health state and tree species. P. radiata, $P$. sylvestris and $P$. nigra seedlings were the most susceptible to A. mellea with $59.6 \%, 57.9 \%$ and $48 \%$ of plants containing lesions, respectively (Figure 9). C. japonica, Q. robur and S. giganteum were the least susceptible species with $0 \%, 5 \%$ and $5.6 \%$ of plants infected, respectively. When the adjusted standardized residuals were examined, $P$. radiata, $P$. sylvestris and $P$. nigra had significant positive values in the lesion category, meaning that more plants than expected by chance had a lesion, and significant negative values in the healthy category, meaning that fewer plants than expected were healthy $(z= \pm 5.4, p<0.001, z= \pm 3.0, p<0.01$ and $z= \pm 3.4 ; p<0.001$, respectively). C. japonica, $Q$. robur and S. giganteum had significant positive values in the healthy category, and significant negative values in the lesion category $(z= \pm 4.2, p<0.001 ; z= \pm 3.4, p<0.001 ; z= \pm 3.1$, $p<0.01$, respectively). F. sylvatica, Prunus avium, Q. petraea, Q. ilex, and E. nitens plants did not show any significant difference between the expected and the observed value (Figure 9).

Tree species with more than three trees containing lesion, and therefore suitable for the Brown-Forsythe and Welch tests, were P. radiata, P. nigra, P. sylvestris, Q. ilex and F. sylvatica. Significant differences in lesion size were found among the tree species (Brown-Forsythe $\mathrm{F}(4,39.364)=9.235, p<$ 0.001 and Welch $\mathrm{F}(4,35.030)=7.255, p<0.001)$. The mean lesion length was highest for $P$. nigra $(16.18$ $\pm 5.03 \mathrm{~cm})$, followed by P. radiata $(12.70 \pm 6.95 \mathrm{~cm})$, P. sylvestris $(12.66 \pm 5.67 \mathrm{~cm})$, Q. ilex $(9.23 \pm 9.25$ $\mathrm{cm})$, and F. sylvatica $(6.75 \pm 4.32 \mathrm{~cm})$ (Figure 10). 


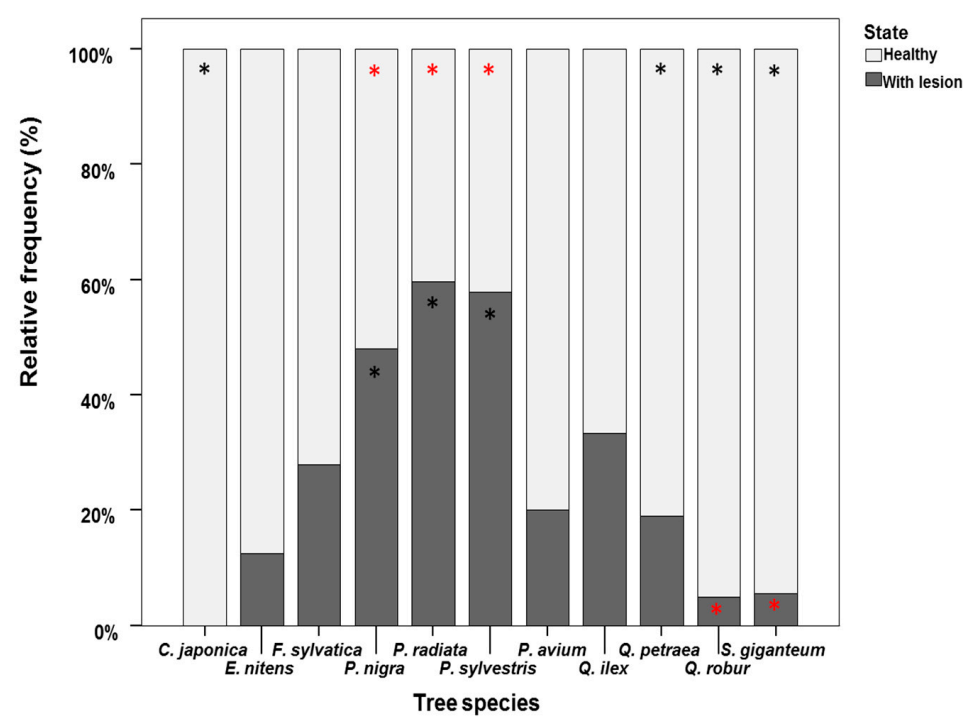

Figure 9. Susceptibility of several tree species found in the Basque Country to A. mellea infection. The relative frequency of healthy young trees and those with fungal lesions was determined four months after infection with $A$. mellea and growth under greenhouse conditions. Counts are represented as percentage of the total number of plants for each tree species. Black asterisks indicate positive significant $z$ scores $(p<0.05)$. Red asterisks indicate negative significant $z$ scores $(p<0.05)$.

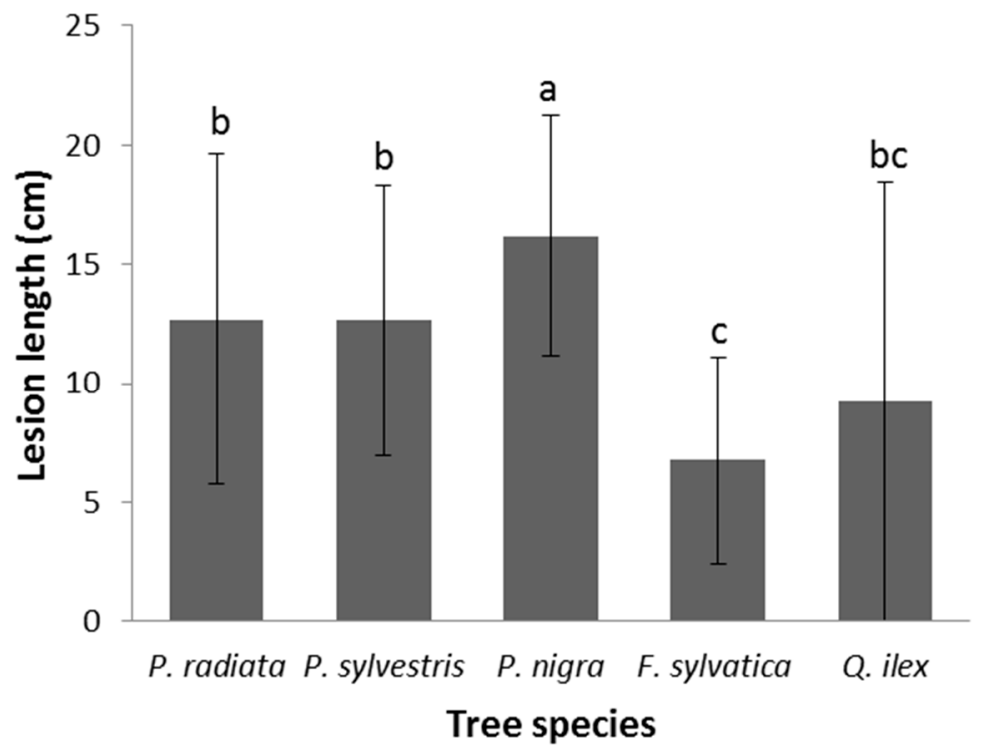

Figure 10. Length of lesions $(\mathrm{cm})$ caused by A. mellea in different tree species. Error bars show the standard deviation of the means. Statistically significant differences of $p<0.05$ between tree species are presented with different lowercase letters.

\section{Discussion}

In the present study, we report the broad distribution of Armillaria spp. in native forests and plantations of the Basque Country and the ecosystem characteristics that may foster the occurrence of this fungal complex. The diversity of the Armillaria population in three of the infected plots was assessed in order to determine their interspecies and intraspecies diversity and potential dispersal mechanisms. Finally, host susceptibility to A. mellea was determined in a set of native and exotic forest species selected on the basis of their presence in the Atlantic area of Spain. 
In the large and small scale surveys, $A$. ostoyae was the predominant species, mainly detected in conifers, but also in native forests of $F$. sylvatica and $Q$. robur. The wide host range displayed by A. mellea in this study has been thoroughly referenced [2,8], and A. gallica was also found in both conifers and deciduous trees.

In the stands infected with Armillaria spp., A. ostoyae was distributed in larger clonal clusters than A. mellea and A. gallica, which were found in medium and small clonal clusters, respectively. Differences in genet size among Armillaria spp. has been previously reported [54-56]. Genet size is influenced by basidiocarp formation, basidiospore abundance and survival, and formation of diploids, which are related to moisture and temperature. The presence of larger genets, which indicates dispersion by vegetative mycelium, is more common in dry and/or cold forests than in moist-warm forests, where dispersion by basidiospores would be favored [54-56]. In the present study the stands with the largest genets, Otxandiano and Altube, experience colder temperatures. However, A. mellea genets were of similar sizes in stands with cold and warmer climate, so differences in behavior among species may also be a factor.

Most of the genets determined for Armillaria spp. by UP-PCR using AS4 primer and SI tests were consistent. In the case of the genet from Otxandiano, no difference in UP-PCR band patterns were apparent between $A$. ostoyae samples, but when A. ostoyae samples located in Altube were assessed, different band patterns were detected among isolates of the same SCG. Different band patterns were also detected among A. gallica isolates of the same SCG. This could mean that some genets were composed of sib-related genets, meaning that basidiospores could be more important in the dispersion process than observed in the SC tests [56]. UP-PCR may provide more information about the genets obtained by SC tests in Armillaria spp. Dodd et al. [57] also used UP-PCR for determining polymorphism within and between different species of Armillaria (A. limonea (G. Stev.) Boesew. and A. novae-zelandiae (G. Stev.) Boesew.), and in their study primer AS4 also provided consistent results.

Although Armillaria spp. were present in forests in the study area with a wide range of environmental conditions, they were more frequently detected in stands with $20-30 \%$ slopes, with a westerly orientation, deciduous forests, acid soils with high permeability, and rainfall average values above $1800 \mathrm{~mm}$. Armillaria spp. were less abundant in stands with slopes less than $10 \%$, southwest orientation, rainfall average values below $1000 \mathrm{~mm}$, and coniferous forests with moderately acidic and medium permeability or impermeable soils. In general, species of the Armillaria complex have been isolated from a wide range of soil and environmental conditions but disease foci are also influenced by host adaptability and stress [7].

A. mellea is recognized as a primary pathogen of a broad range of tree species. In the present study, A. mellea had the highest host diversity at the stand level. This was also observed by Pintos et al. [58] when different soils from Pontevedra, Galicia, Spain were analyzed for the presence of Armillaria spp., and in general for European populations [2]. To confirm the host range in trees that are predominant in the Basque Country, and to identify resistance species, their susceptibility was tested under greenhouse conditions. All the tested tree species except $C$. japonica were susceptible to A. mellea. Melo et al. [59] determined that resistance of $C$. japonica was due to the presence of polyphenolic compounds in the heartwood [60]. Pinus species were the most affected by A. mellea infection. Aguín et al. [61] reported that Pinus spp. infected with A. mellea were the first to show aerial symptoms of disease in comparison to those infected with other species of Armillaria, such as A. ostoyae and A. gallica. In this study, P. radiata had the most infected plants and P. nigra had the largest average lesion size. P. radiata is known to be very susceptible to other Armillaria spp. such as A. novae-zelandiae [62]. C. japonica has been reported tolerant to Fusarium circinatum Nirenberg \& O'Donnell [63], since both diseases are present in this region and the area shows optimal growth conditions for this tree species it could be considered a promising alternative to $P$. radiata in monoculture plantations. However, in the present susceptibility assay only $A$. mellea pathogenicity was examined in greenhouse conditions, so this result should be considered as preliminary findings. 
While Armillaria was found to be associated with mortality in the forests of the Basque Country, the impact of the fungus can be difficult to evaluate because it is influenced by other biotic and abiotic elements of the ecosystem. Armillaria spp. can cause mortality in susceptible tree species, however, sometimes their effects are less visible and infection does not always have a negative impact on tree development. The outcome of infection is also influenced by forest management strategies and this study is a first attempt to define factors that contribute to the development of Armillaria disease in the area, bearing in mind the complex etiology of this pathosystem.

\section{Conclusions}

Although Armillaria was frequently detected in the studied native and plantation forests, control measures have been restricted to urban trees and recreational parks, and implemented to prevent civilian and structural damage that may be caused by instability of affected trees. The control of Armillaria complex in forests is more difficult as it is spread over a wider area, often in areas that are difficult to access. The best way to reduce the vigor of the fungus, which is strongly dependent on the availability of food sources, is by pulling out infected stumps and roots. However, this measure can also disrupt beneficial microbial populations [64], which may act as a natural control of pathogens [65]. Fungicidal treatments can kill the fungus in the soil; however, the economic and environmental costs are high. By contrast, early detection of disease and treatment with effective biological antagonists, and planting Armillaria-tolerant tree species are recommended for forests, plantations, urban areas and recreational parks [66]. In typical modern plantations, control measures are probably economically justified if mortality from Armillaria spp. is severe early in the previous rotation. It is, therefore, important to keep good stand records that will point out the impact of different factors when a decision may be necessary prior to planting a new species. Even if action is not taken, forest owners should be aware of the presence of the fungi, especially if there is a chance that a change of management practice could inadvertently lead to an increase in disease impact $[14,18,20]$.

Acknowledgments: To perform this study the authors were funded by their respective institutions and by the Research University Department of the Basque Government, the Project RTA 2013-00048-C03-03 INIA and the Project: Healthy Forest: LIFE14 ENV/ES/000179.

Author Contributions: Nebai Mesanza, Cheryl L. Patten and Eugenia Iturritxa developed conceptual ideas, designed the study and wrote the paper. Nebai Mesanza and Eugenia Iturritxa conducted sampling in field, analysis of samples in the lab, and data analysis.

Conflicts of Interest: The authors declare no conflict of interest.

\section{References}

1. Wingfield, M.J.; Coetzee, M.P.A.; Crous, P.W.; Six, D.; Wingfield, B.D. Fungal phoenix rising from the ashes? IMA Fungus 2011, 1, 149-153. [CrossRef]

2. Guillaumin, J.J.; Mohammed, C.; Anselmi, N.; Courtecuisse, R.; Gregory, S.C.; Holdenrieder, O.; Intini, M.; Lung, B.; Marxmüller, H.; Morrison, D.; et al. Geographical distribution and ecology of the Armillaria species in western Europe. For. Pathol. 1993, 23, 321-341. [CrossRef]

3. Pérez-Sierra, A.; Henricot, B. Identification of fungal species beyond morphology. Mycologist 2002, 16, 42-46. [CrossRef]

4. Williams, R.E.; Shaw, C.G., III; Wargo, P.M.; Sites, W.H. Armillaria Root Disease. In Forest Insect and Disease Leaflet 78; USDA Forest Service: Washington, DC, USA, 1989.

5. Cox, K.D.; Scherm, H.; Beckman, T.G. Armillaria root and crown rot. In Southeastern Peach Growers Handbook; Horton, D., Johnson, D., Eds.; Cooperative Extension Service, University of Georgia: Athens, GA, USA, 2005; pp. 162-166.

6. Edmonds, R.L.; Agee, J.K.; Gara, R.I. Root Diseases. In Forest Health and Protection; Edmonds, R.L., Agee, J.K., Gara, R.I., Eds.; McGraw-Hill Companies, Inc.: New York, NY, USA, 2000; pp. 275-308. 
7. Wargo, P.M.; Harrington, T.C. Host stress and susceptibility. In Armillaria Root Disease; Shaw, C.G., III, Kile, G.A., Eds.; Agriculture Handbook No. 691; USDA Forest Service: Washington, DC, USA, 1991; pp. 88-101.

8. Guillaumin, J.J.; Legrand, P. Armillaria root rots. In Infectious Forest Diseases; Gonthier, P., Nicolotti, G., Eds.; CAB International: Wallingford, UK, 2013; pp. 159-168.

9. Kile, G.A. Armillaria root rot in eucalypt forests aggravated endemic disease. Pac. Sci. 1983, 37, 459-464.

10. Mallett, K.I.; Volney, W.J.A. Relationships among jack pine budworm damage, selected tree characteristics, and Armillaria root rot in jack pine. Can. J. For. Res. 1990, 20, 1791-1795. [CrossRef]

11. Entry, J.A.; Cromack, K.J.; Hansen, E.; Waring, R. Response of western coniferous seedlings to infection by Armillaria ostoyae under limited light and nitrogen. Phytopathology 1991, 81, 89-94. [CrossRef]

12. Mallett, K.; Maynard, D. Armillaria root disease, stand characteristics, and soil properties in young lodgepole pine. For. Ecol. Manag. 1998, 105, 37-44. [CrossRef]

13. Popoola, T.O.S.; Fox, R.T.V. In vitro growth response of Armillaria isolates to different carbohydrate sources. ASSET Ser. B 2003, 2, 29-37.

14. Hood, I.A.; Kimberley, M.O. Impact of Armillaria root disease and the effect of thinning in a late-rotation Pinus. radiata plantation. For. Pathol. 2009, 39, 415-427. [CrossRef]

15. Wargo, P.M.; Shaw, C.G., III. Armillaria root rot: the puzzle is being solved. Plant Dis. 1985, 6, 826-832. [CrossRef]

16. Gerlach, J.P.; Reich, P.B.; Puettman, K.; Baker, T. Species, diversity, and density affects tree seedling mortality from Armillaria root rot. Can. J. For. Res. 1997, 27, 1509-1512. [CrossRef]

17. Kromroy, K.W.; Blanchette, R.A.; Grigal, D.F. Armillaria species on small woody plants, small woody debris, and root fragments in red pine stands. Can. J. For. Res. 2005, 35, 1487-1495. [CrossRef]

18. Bloomberg, W.J.; Morrison, D.J. Relationship of growth reduction in Douglas-fir to infection by Armillaria root disease in southeastern British Columbia. Phytopathology 1989, 79, 482-487. [CrossRef]

19. Morrison, D.J.; Merler, H.; Norris, D. Detection, Recognition and Management of Armillaria and Phellinus Root Diseases in the Southern Interior of British Columbia; FRDA II Rep.; British Columbia; Ministry of Forests, Research Branch: Victoria, BC, Canada, 1991.

20. Hood, I.A.; Sandberg, C.J. Armillaria-A hidden disease of Pinus radiata. N. Z. J. For. Sci. 1993, 38, $29-32$.

21. Redfern, D.B.; Filip, G.M. Inoculum and infection. In Armillaria Root Disease; Shaw, C.G., III, Kile, G.A., Eds.; Agriculture Handbook No. 691; USDA Forest Service: Washington, DC, USA, 1991; pp. 48-61.

22. Kliejunas, J.T. A risk assessment of climate change and the impact of forest diseases on forest ecosystems in the Western United States and Canada. In Gen. Tech. Rep. PSW-GTR-236. Albany, CA: U.S. Department of Agriculture, Forest Service, Pacific Southwest Research Station; Pacific Southwest Research Station: Albany, CA, USA, 2011; p. 70.

23. Baumgartner, K.; Coetzee, M.P.A.; Hoffmeister, D. Secrets of the subterranean pathosystem of Armillaria. Mol. Plant Pathol. 2011, 12, 515-534. [CrossRef] [PubMed]

24. Korhonen, K. Interfertility and clonal size in the Armillariella mellea complex. Karstenia 1978, 18, 31-42.

25. Bulat, S.A.; Mironenko, N.V. Species identity of the phytopathogenic fungi Pyrenophora teres Dreschler and P. graminea Ito \& Kuribayashi. Mikol. Fitopatol. 1990, 24, 435-441. (In Russian)

26. Nielsen, K.; Justesen, A.F.; Jensen, D.F.; Yohalem, D.S. Universally primed polymerase chain reaction alleles and internal transcribed spacer restriction fragment length polymorphisms distinguish two subgroups in Botrytis aclada distinct from B. byssoidea. Phytopathology 2001, 91, 527-533. [CrossRef] [PubMed]

27. Meyling, N.V.; Elinberg, J. Isolation and characterization of Beauveria bassiana isolates from phylloplanes of hedgerow vegetation. Mycol. Res. 2006, 11, 188-195. [CrossRef] [PubMed]

28. Pottinger, B.; Stewart, A.; Carpenter, M.; Ridgway, H.J. Low genetic variation detected in New Zealand populations of Phaeomoniella. chlamydospora. Phytopathol. Mediterr. 2002, 41, 199-211.

29. Bulat, S.A.; Lúbeck, M.; Mironenko, N.V.; Jensen, D.F.; Lübeck, P.S. UP-PCR analysis and ITS1 ribotyping of Trichoderma and Gliocladium. Mycol. Res. 1998, 102, 933-943. [CrossRef]

30. Aguín, O.; Mansilla, J.P.; Sainz, M.J. Intraspecific variation in Armillaria species from shrubs and trees in northwestern Spain. Phytopathol. Mediterr. 2004, 43, 299-304.

31. Escofet, P.E.; Aguín, O.; Mansilla, J.P. Detección e identificación por técnicas moleculares de especies del género Armillaria a partir de muestras de suelo. Bol. San. Veg. Plagas. 2006, 32, 231-240. 
32. Oliva, J.; Suz, L.M.; Colinas, C. Ecology of Armillaria species in silver fir (Abies alba) stands of the Spanish Pyrenees. Ann. For. Sci. 2009, 66, 603. [CrossRef]

33. Iturritxa, E.; León, M.; García-Serna, I.; Heppe, E.; García-Jiménez, J.; Pérez-Sierra, A. Distribution and ecology of Armillaria species in northern Spain. In Root and Butt Rots of Forest Trees, Proceedings of the IUFRO, Berkeley, CA, USA, 12 August 2007; Garbelotto, M., Gonthier, P., Eds.; The university of California: Berkeley, CA, USA, 2008.

34. HAZI. El Bosque Vasco en Cifras. Available online: http://www.nasdap.ejgv.euskadi.eus/contenidos/ informacion/inventario_forestal_2011/es_agripes/adjuntos/El\%20bosque\%20vasco\%20en \%20cifras \% 202011_2012.pdf (accessed on 26 January 2017).

35. Basque Government. Available online: http://www.nasdap.ejgv.euskadi.eus/nota_prensa/2016/el-sectorforestal-madera-de-euskadi-genera-18-000-empleos-y-aporta-el-1-53-del-pib-vasco-segun-los-datosaportados-por-el-libro-blanco-del-sector/r50-promocon/es/ (accessed on 26 January 2017).

36. Mueller-Dombois, L.D.; Ellenberg, H. Measuring Species Quantities. In Aims and Methods of Vegetation Ecology; John Wiley and Sons: New York, NY, USA, 1974; pp. 67-92.

37. Worrall, J.J. Media for selective isolation of Hymenomycetes. Mycologia 1991, 83, 296. [CrossRef]

38. Pitt, J.I.; Hocking, A.D. Preservation of fungi. In Fungi and Food Spoilage, 3rd ed.; Springer: New York, NY, USA, 2009; pp. 48-50.

39. Greenacre, M.; Hastie, T. The Geometric Interpretation of Correspondence Analysis. J. Am. Stat. Assoc. 1987, 82, 437-447. [CrossRef]

40. Field, A.P. Discovering Statistics Using SPSS: (and Sex and Drugs and Rock ' $n$ ' Roll); SAGE Publications: London, UK, 2009.

41. Harrington, T.C.; Wingfield, B.D. A PCR based identification method for species of Armillaria. Mycologia 1995, 87, 280-288. [CrossRef]

42. Pérez-Sierra, A.; Whitehead, D.S.; Whitehead, M.P. Investigation of a PCR-based method for the routine identification of British Armillaria species. Mycol. Res. 1999, 103, 1631-1636. [CrossRef]

43. Anderson, J.B.; Ullrich, R.C.; Roth, L.F.; Filip, G.M. Genetic identification of clones of Armillaria mellea in coniferous forests in Washington. Analysis 1979, 69, 1109-1111.

44. Tyson, J.L.; Ridgway, H.J.; Fullerton, R.A.; Stewart, A. Genetic diversity in New Zealand populations of Sclerotium cepivorum. N. Z. J. Crop Hortic. Sci. 2002, 30, 37-41. [CrossRef]

45. Lamboy, W.F. Computing genetic similarity coefficients from RAPD data: The effects of PCR artifacts. PCR Methods Appl. 1994, 4, 31-37. [CrossRef] [PubMed]

46. Dunn, G.; Everitt, B.S. An introduction to Mathematical Taxonomy; Cambridge University Press: Cambridge, UK, 1982.

47. Bulat, S.A.; Mironenko, N.V.; Lapteva, M.N.; Strelchenko, P.P. Polymerase chain reaction with universal primers (UP-PCR) and its application to plant genome analysis. In Conservation of Plant Genes II: Utilization of Ancient and Modern DNA; Adams, R.P., Miller, J.S., Goldenberg, E.M., Adams, J.E., Eds.; Missouri Botanical Garden: St. Louis, MO, USA, 1994; Volume 48, pp. 113-129.

48. Bulat, S.A.; Lübeck, M.; Alekhina, I.; Jensen, D.F.; Knudsen, I.M.B.; Lübeck, P.S. Identification of an UP-PCR derived marker for an antagonistic strain of Clonostachys rosea and development of a strain-specific PCR detection assay. Appl. Environ. Microbiol. 2000, 66, 4758-4763. [CrossRef] [PubMed]

49. Lübeck, P.S.; Alekhina, I.A.; Lübeck, M.; Bulat, S.A. UP-PCR genotyping and rDNA analysis of Ascochyta pisi Lib. J. Phytopathol. 1998, 146, 51-55. [CrossRef]

50. Lübeck, M.; Alekhina, I.A.; Lübeck, P.S.; Jensen, D.F.; Bulat, S.A. Delineation of Trichoderma harzianum into two different genotypic groups by a highly robust fingerprinting method, UP-PCR, and UP-PCR product cross hybridisation. Mycol. Res. 1999, 103, 289-298. [CrossRef]

51. Bulat, S.A.; Mironenko, N.V.; Zholkevich, Yu.G. Genetic structure of soil population of fungus Fusarium oxysporum Schlechtend.: Fr.: Molecular reidentification of the species and genetic differentiation of strains using polymerase chain reaction technique with universal primers (UP-PCR). Russ. J. Genet. 1995, 31, 271-278.

52. Meyer, W.; Koch, A.; Niemann, C.; Beyermann, B.; Epplen, J.T.; Börner, T. Differentiation of species and strains among filamentous fungi by DNA fingerprinting. Curr. Genet. 1991, 19, 239-242. [CrossRef] [PubMed] 
53. Nogales, A.M. Estudio de la Interacción Entre el Hongo Formado de Micorrizas Arbusculares Glomus intraradices Schenck y Smith y el hongo patógeno Armillaria mellea (Vahl.:fr) P.Kuhn en vid. Doctoral Thesis, Universitat de Barcelona, Barcelona, Spain, 2009.

54. Ferguson, B.A.; Dreisbach, T.A.; Parks, C.G.; Filip, G.M.; Schmitt, C.L. Coarse-scale population structure of pathogenic Armillaria species in a mixed-conifer forest in the Blue Mountains of northeast Oregon. Can. J. For. Res. 2003, 33, 612-623. [CrossRef]

55. Worrall, J.J.; Sullivan, K.F.; Harrington, T.C.; Steimel, J.P. Incidence, host relations and population structure of Armillaria ostoyae in Colorado campgrounds. For. Ecol. Manag. 2004, 192, 191-206. [CrossRef]

56. Bendel, M.; Kienast, F.; Rigling, D. Genetic population structure of three Armillaria species at the landscape scale: A case study from Swiss Pinus mugo forests. Mycol. Res. 2006, 110, 705-712. [CrossRef] [PubMed]

57. Dodd, S.L.; Shah, F.H.; Hood, I.A. Molecular tools to determine the mode of spread of the root pathogen Armillaria in commercial pine forests. (Poster abstract AP-493). In Proceedings of the Joint Meeting of the American Phytopathological Society, Canadian Phytopathological Society, and the Mycological Society of America, Québec City, QC, Canada, 29 July-2 August 2006; (CD-ROM) American Phytopathological Society: St Paul, MN, USA, 2006.

58. Pintos, C.; Aguín, O.; Mansilla, P.; Rial, C.; Sainz, M.J.; Salinero, M.C.; Mansilla, J.P. Diagnóstico de especies de Armillaria y Phytophthora en suelo como estrategia de conservación de árboles singulares en Galicia. In Montes: Servicio Y Desarrollo Rural, Proceedings of the $6^{\circ}$ Congreso Forestal, Vitoria-Gasteiz, Spain, 10-14 June 2013; Sociedad Española de Ciencias Forestales: Madrid, Spain, 2014.

59. Melo, M.J.; Machado, M.H.; Moniz, M. de F.; Bragança, M.H.; Sousa Santos, M.N. Resistance patterns of Cryptomeria japonica to Armillaria mellea in S. Miguel Island-Azores. In Proceedings of the Poster 4J Congresso da Sociedade Portuguesa de Fitopatologia, Universidade do Algarve, Faro, Portugal, 4-6 February 2004.

60. Azevedo, N. Significance of rhizomorph formation of Armillaria mellea (Fr.) Kum. on Cryptomeria japonica (L.f.) D. Don in Azores. Phytopathol. Mediterr. 1976, 15, 73-77.

61. Aguín, O.; Mansilla, J.P.; Sáinz, M.J. Patogenicidad de Armillaria mellea, Armillaria ostoyae y Armillaria gallica sobre coníferas. In Proceedings of the XII Congreso de la Sociedad española de fitopatología, Lloret de Mar, Spain, 26 September-1 October 2004.

62. Hood, I.A.; Kimberley, M.O.; Gardner, J.F. Susceptibility to Armillaria novae-zelandiae among clones of Pinus radiata. For. Pathol. 2009, 39, 405-414. [CrossRef]

63. Iturritxa, E. Análisis de la Sanidad y Desarrollo de Métodos de Protección de las Masas Forestales en la C.A.P.V. Available online: http:/ / www.osakidetza.euskadi.eus/contenidos/documentacion/forpato/es_ agripes/adjuntos/FORPATO2013.pdf (accessed on 6 May 2017).

64. Butin, H. Tree Diseases and Disorders; Oxford University Press: Oxford, UK, 1995.

65. Mesanza, N.; Iturritxa, E.; Patten, C.L. Native rhizobacteria as biocontrol agents of Heterobasidion annosum s.s. and Armillaria mellea infection of Pinus. radiata. Biol. Control. 2016, 101, 8-16. [CrossRef]

66. Schwarze, F.W.M.R. Diagnosis and Prognosis of the Development of Wood Decay in Urban Trees; ENSPEC: Rowville, Australia, 2008; p. 336.

(C) 2017 by the authors. Licensee MDPI, Basel, Switzerland. This article is an open access article distributed under the terms and conditions of the Creative Commons Attribution (CC BY) license (http://creativecommons.org/licenses/by/4.0/). 